\title{
A case of Plasmodium vivax malaria with respiratory failure
}

\author{
Solunum yetmezliğinin eşlik ettiği Plasmodium vivax malaria olgusu
}

Hülya Günbatar ${ }^{1}$, Bünyamin Sertoğullarından ${ }^{1}$, Selami Ekin ${ }^{1}$, Bülent Özbay ${ }^{1}$, Aysel Sünnetcioğlu ${ }^{2}$

\begin{abstract}
Acute renal failure disseminated intravascular coagulation, acute respiratory distress syndrome (ARDS), hypoglycemia, coma or epileptic seizures are manifestations of severe Plasmodium (P.) falciparum malaria. $P$. vivax malaria is rarely associated with severe complications. We report a case of 30-year-old male refugee coming from Pakistan, has been found in hospital garden as unconscious. After therapy of pneumonia requiring intensive care unit and intensive supportive care, the patient left invasive mechanical ventilation (IMV). Because of continued fever and chills attacks focused on malaria diagnosis, Plasmodium vivax malaria detected on thick peripheral blood smear. After intensive supportive care and specific anti-plasmodial therapy, the patient recovered and was discharged from hospital. The use of IMV vivax-malaria related ARDS was associated with a good outcome. $J$ Clin Exp Invest 2013; 4 (2): 226-228
\end{abstract}

Key words: ARDS, Plasmodium vivax, pneumonia, respiratory failure

\section{INTRODUCTION}

Malaria is a parasitic disease transmitted through the bite of infected Anopheles mosquitoes. P. falciparum and $P$. vivax are responsible for most of the global burden of malaria. More than two billion people are at the risk of contracting malaria [1], especially in the tropical and subtropical countries. Symptoms of $P$. vivax malaria are parallel to other species of malaria and include cyclical fever with chills, vomiting, headache, weakness and diarrhoea. The manifestations of severe malaria contain cerebral malaria, hemoglobinuria, pulmonary edema or acute respiratory distress syndrome (ARDS), abnormalities in blood coagulation and thrombocytopenia, severe anemia, cardiovascular collapse, shock, acute kidney failure, metabolic acidosis and hypoglycemia. In contrast to falciparum malaria, vivax malaria is

\section{ÖZET}

Akut böbrek yetmezliği, dissemine intravasküler koagülasyon, akut solunum sıkıntısı sendromu (ARDS), hipoglisemi, koma veya epileptik nöbet ağır Plasmodium falciparum'un bulgularıdır. Plasmodium vivax nadiren ciddi komplikasyonlara neden olur. Hastane bahçesinde bilinçsiz olarak bulunan 30 yaşında erkek Pakistanlı mülteci bir olguyu sunuyoruz. Yoğun bakım desteği gerektiren pnömoni tedavisi ve yoğun bakım desteğinden sonra invaziv mekanik ventilasyondan ayrıldı. Devam eden ateş ve titreme atakları nedeniyle sıtma tanısı üzerine odaklanıldı, Plasmodium vivax kalın periferik yaymada tespit edildi. Yoğun bakım desteği ve spesifik antiplasmodial tedavi sonrası hasta iyileşti ve hastaneden taburcu edildi. ARDS ilişkili Plasmodium vivax'da mekanik ventilasyon kullanımı olumlu sonuçla ilişkiliydi.

Anahtar kelimeler: ARDS, Plasmodium vivax, pnömoni, Solunum yetmezliği

rarely associated with serious complication. However, impaired alveolar-capillary membrane functions were seen in patients with severe malaria. It was thought that $P$. vivax might cause severe complications only where the possibility of mixed infections exists [2]. Plasmodium vivax-associated ARDS is a clinically recognizable condition whose underlying pathophysiology is likely to reflect processes that are independent of parasite sequestration in the pulmonary microvasculature [3]. We report a case of ARDS complicating infection with Plasmodium vivax malaria.

\section{CASE}

A 30-year-old male patient was found in hospital garden as unconscious. He was a refugee from Pakistan; He was unable to give a history of him-

\footnotetext{
${ }^{1}$ Department of Pulmonary and Critical Care, Medical Faculty of Yüzüncü Yıl University, Van, Turkey

${ }^{2}$ Department of Pulmonary and Critical Care, Van Regional Training and Research Hospital, Van, Turkey

Correspondence: Hülya Günbatar,

Yüzüncü Yıl Üniversitesi D. Odabaş Tıp Merkezi Kampüsü, Van, Türkiye Email: hulyagunbatar@hotmail.com Received: 30.01.2013, Accepted: 07.02.2013

Copyright (C) JCEI / Journal of Clinical and Experimental Investigations 2013, All rights reserved
} 
self. The patient had no past medical history. On admission, he was unconscious, none oriented, and a general examination revealed a fever $\left(99.6^{\circ} \mathrm{F}\right)$, mild hypotension $(100 / 70 \mathrm{mmHg})$, a pulse rate of 88 beats $/ \mathrm{min}$, and respiratory rate of $35 / \mathrm{min}$. Systemic examination was normal. Arterial blood gas analysis showed $\mathrm{pH}-7.42, \mathrm{pO}_{2}-64.7 \mathrm{mmHg}, \mathrm{pCO}_{2}-33.2$ $\mathrm{mmHg}, \mathrm{HCO}_{3}-21.8 \mathrm{mmol} / \mathrm{L}$, and $\mathrm{PaO}_{2} / \mathrm{FiO}_{2}$ ratio of 161 with 5 litre of oxygen per minute. Because of mental confusion, he was entubated, transferred to the intensive care unit. Laboratory investigations had abnormalities: mild anemia and trombositopenia (red blood cells count $=4.24 \times 10^{3} / \mathrm{ml}$ and, platelet count $=130 \times 10^{3} / \mathrm{ml}$ ). The periferal blood smear showed hypochromic micrositic anemia, mild trombositopenia, no any parasite or microorganism observed. In the urinalysis urobilinogen was positive. Lactate dehidrogenase $(2255 \mathrm{U} / \mathrm{L})$, creatine kinase (2256 U/L), AST (89 U/L) values was higher in blood analyses. The chest X-ray showed bilateral non-homogenous opacities consistent with atypical pnömonia. He received ceftriaxone for treatment of pneumonia requiring intensive care unit and oseltamivir likely exposure of viruses. He was investigated about likely epilepsy by neurology; his brain computed tomography examination showed mild brain edema and antiedema therapy started. Lumbar punction was performed to the patient, no cell found in the cerebrospinal liquid. Echocardiography revealed normal cardiac function.

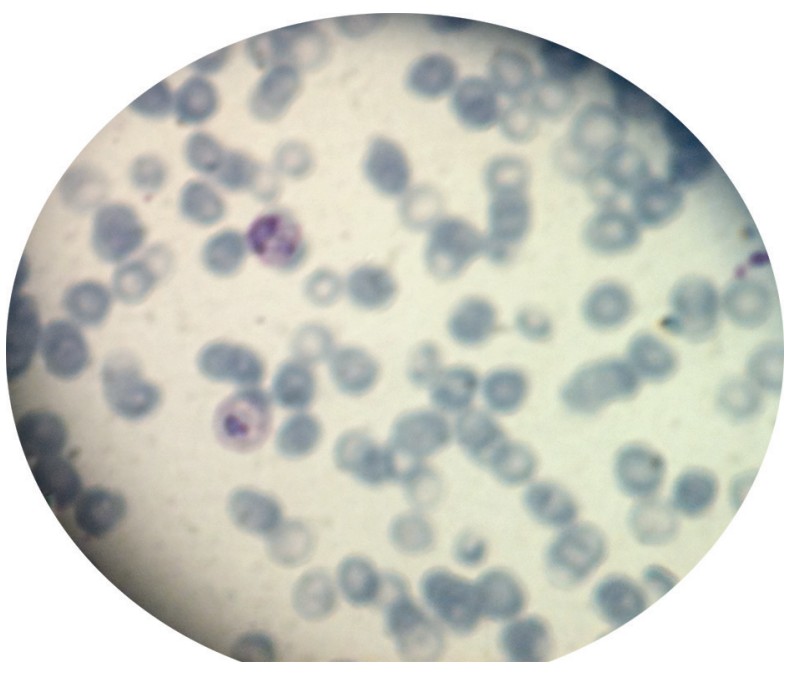

Figure 1. The peripheral blood thick smear of patient showed trophozoites and schizonts of Plasmodium vivax

Despite all the treatment he had fever and chills intermittently. On Day 3 of intensive care, the patient was hemodynamically stable. A significant improvement was seen on the chest X-ray, the patient left mecanical ventilation. Blood and urine cultures were sterile. His antibiotheraphy completed in seven days, because of intermittant fever and chills attach malaria was persistently thought. Help asked from association of malaria war. The peripheral blood thick smear showed trophozoites and schizonts of Plasmodium vivax (figure 1). Specific anti-plasmodial therapy was started chloroquine for three days and primaquine for fourteen days with supportive therapy. The patient was discharged from the hospital after 20 days.

\section{DISCUSSION}

This case represents one of the rare occasions where respiratory complication was observed with Plasmodium vivax malaria. The absence of cardiac factors for pulmonary edema and with the presence of trophozoites and schizonts of Plasmodium vivax on the peripheral smear, establishes the diagnosis of ARDS due to Plasmodium vivax malaria.

There are only a few reports of ARDS in Plasmodium vivax infected cases [4]. Nayak, et al investigated 200 cases of severe malaria about pulmonary manifestations [5]. ARDS was presented in 14 malaria patients. Their findings were comparatively higher than that seen in similar studies [6].

The essential pathologic feature of severe malaria is sequestration of erythrocytes, which contain mature forms of the parasite in the deep vascular beds of vital organs and rosette formation, thus producing organ dysfunction.

The mechanisms underlying lung damage caused by Plasmodia are not well understood. Red blood cells parasitized by Plasmodium vivax do not cytoadhere to endothelial cells; thus, the occurrence of ARDS in malaria suggests that lung injury in malaria cases is also not related to the microvascular sequestration of parasitized red blood cells. Anstey et al. suggest that lung monocyte accumulation occurs in vivax and ovale malaria, as well as in falciparum malaria, with intravascular inflammatory changes contributing to impaired gas transfer and respiratory manifestations [7].

Recent in vitro but not in vivo data suggest that Plasmodium vivax-infected red cells may cytoadhere to the endothelial cell ligand chondroitin sulfate A (CSA) [8]. Apart from the placenta, the other human endothelial cells known to express CSA are the lung and brain and this may explain the occurrence of ARDS and cerebral malaria in patients with vivax malaria. In fact, along with alveolar epithelial inflammation, ARDS has been associated with more 
systemic inflammatory response systems including activation of neutrophils and cytokines.

The frequent onset of ARDS after starting antimalarial treatment may reflect a post-treatment exacerbation of inflammatory response mediated by proinflammatory cytokine release. Thus, the parasite probably triggers a hyperimmune response with resultant lung injury. Severe pulmonary complications of vivax malaria usually appear from six hours to eight days after the initiation of anti-malarial treatment and they could correspond to an exacerbation of the post-treatment inflammatory response [7]. However, severe pulmonary symptoms may occur before the initiation of anti-malarial treatment $[5,6]$. Withal severe pulmonary symptoms may occur after the initiation of anti-malarial treatment [9]. In our case severe pulmonary symptoms, ARDS developed before starting chloroquine. The diagnosis of vivax malaria was made by examination of periferic blood film. The diagnosis of ARDS was confirmed by excluding cardiac disease by echocardiography.

Treatment of ARDS usually requires institution of invasive mechanical ventilation with high PEEP. However, in a systematic review of the literature for the use of noninvasive ventilation (NIV) in cases of acute lung injury (ALI) / ARDS related to $P$. vivax, Agarwal et al, found that the use of NIV in vivax malaria related ALI / ARDS is associated with a good outcome [10]. Early institution of mechanical ventilation with high PEEP was proved to be life-saving in this case.

As a conclusion we are reporting a middleaged men suffering from vivax malaria complicated with ARDS, it may be suggested that vivax malaria can cause ARDS and this point should be kept in mind while treating such patients. The use of NIV or
IMV in Plasmodium vivax related ARDS is associated with a good outcome.

\section{REFERENCES}

1. Greenwood BM, Fidock DA, Kyle DE, et al. Malaria: progress, perils, and prospects for eradication. J Clin Invest 2008;118:1266-1276.

2. Kumar S, Melzer M, Dodds $P$, et al. Vivax malaria complicated by shock and ARDS. Scand J Infect Dis. 2007;39:255-256.

3. Price L, Planche T, Rayner C, Krishna S. Acute respiratory distress syndrome in Plasmodium vivax malaria: Case report and review of the literature. Trans $\mathrm{R}$ Soc Trop Med Hyg 2007;101:655-659.

4. Kasliwal P, Rao MS, Kujur R. Plasmodium vivax malaria: An unusual presentation. Indian J Crit Care Med 2009;13:103-105.

5. Nayak KC, Mohini S, Kumar RS, et al. A study on pulmonary manifestations in patients with malaria from Northwestern India (Bikaner). J Vector Borne Dis 2011;48:219-223.

6. Mishra U, Ray G. Pulmonary manifestation of malaria. Chest 2005;128:376.

7. Anstey NM, Jacups SP, Cain T, et al. Pulmonary manifestations of uncomplicated falciparum and vivax malaria: cough, small airways obstruction, impaired gas transfer, and increased pulmonary phagocytic activity. J Infect Dis 2002;185:1326-1334.

8. McGready R, Davison BB, Stepniewska K, et al. The effects of Plasmodium falciparum and $P$. vivax infections on placental histopathology in an area of low malaria transmission. Am J Trop Med Hyg 2004;70:398-407.

9. Sarkar S, Saha K, Das CS. Three cases of ARDS: An emerging complication of Plasmodium vivax malaria. Lung India 2010;27:154-157.

10. Agarwal R, Nath A, Gupta D. Noninvasive ventilation in Plasmodium vivax related ALI/ARDS. Intern Med. 2007;46:2007-2011. 